\title{
Synthesis and bioactivity of pyrrole-conjugated phosphopeptides
}

\author{
Qiuxin Zhang, Weiyi Tan and Bing Xu*
}

\author{
Full Research Paper \\ Address: \\ Department of Chemistry, Brandeis University, 415 South Street, \\ Waltham, MA 02454, USA \\ Email: \\ Bing Xu* - bxu@brandeis.edu \\ * Corresponding author \\ Keywords: \\ cells; enzyme; N-terminal; peptides; pyrroles; self-assembly
}

\author{
Beilstein J. Org. Chem. 2022, 18, 159-166. \\ https://doi.org/10.3762/bjoc.18.17 \\ Received: 04 November 2021 \\ Accepted: 21 January 2022 \\ Published: 31 January 2022 \\ Associate Editor: K. N. Allen \\ (C) 2022 Zhang et al.; licensee Beilstein-Institut. \\ License and terms: see end of document.
}

\begin{abstract}
Here we report the synthesis and effect on the cell viability of pyrrole-conjugated phosphopeptides. Encouraged by the selective inhibition of cancer cells by a naphthyl-capped phosphopeptide (Nap- $\left.\mathrm{ff}_{\mathrm{p}} \mathrm{y}, \mathbf{1}\right)$, we conjugated the heteroaromatic dipyrrole or tripyrrole motif at the N-terminal of short peptides containing phosphotyrosine or phosphoserine and examined the bioactivity of the resulting phosphopeptides (2-10). Although most of the phosphopeptides exhibit comparable activities with that of $\mathbf{1}$ against HeLa cells at $200 \mu \mathrm{M}$, they, differing from 1, are largely compatible with HeLa cells at $400 \mu \mathrm{M}$. Enzymatic dephosphorylation of 2-10, at $400 \mu \mathrm{M}$ is unable to induce a dramatic morphological transition of the peptide assemblies observed in the case of $\mathbf{1}$. These results suggest that a heteroaromatic motif at the N-terminal of peptides likely disfavors the formation of extensive nanofibers or morphological changes during enzymatic self-assembly, thus provide useful insights for the development of phosphopeptides as substrates of phosphatases for controlling cell fate.
\end{abstract}

\section{Introduction}

Biomacromolecular assemblies have received considerable attention recently in the field of biomaterials [1-7], among which peptides are of particular interest because of their unique merits, such as ease of design and tailoring (based on the known structures from proteins), good biocompatibility and degradability, and low immunogenicity. For example, recent works have demonstrated the potential of peptide assemblies for a wide range of applications, including drug delivery [8-11], collagen mimic [12], antibacterial [13,14], biomineralization
[15,16], mimicry of amyloids [17], cell cultures [18], and tissue engineering [19]. Particularly, the use of enzyme-instructed self-assembly (EISA) [20,21] of peptide assemblies has expanded the applications of peptide assemblies, such as intracellular phase transition [22], molecular imaging [23-33], anisotropic hydrogels [34,35], targeting subcellular organelles [36-40], elimination of pluripotent stem cells (PSC) [41,42], and cancer therapy [43-54]. Being a multistep molecular process to generate non-diffusive peptide assemblies, EISA is a 
facile and useful approach to explore the emergent properties of peptide assemblies [55-59] in cellular environment. One of the most explored EISA processes is the use of alkaline phosphatase (ALP) to convert the micelles made of phosphopeptides to the nanofibers of peptides via enzymatic dephosphorylation [20,60]. While ALP-catalyzed EISA has received considerable exploration, the structures of the peptide substrates mainly have centered on naphthylacetyl-capped phosphopeptides (e.g., Nap-ff $\mathrm{py}(\mathbf{1})$ ) [36,61-66]. Considering naphthyl is an aromatic group, we decided to explore other aromatic N-terminal capping groups, such as heteroaromatic, $\mathrm{N}$-terminal capping groups of phosphopeptides for EISA because they receive little exploration [67].

Our previous studies have shown nucleobases, as the heteroaromatic groups, are able to act as the N-capping group for EISA of phosphopeptides [67]. In this study, we chose to examine a different type of heteroaromatic group, pyrroles, because pyrrole is adaptable for solid-phase synthesis [68] so that it is feasible to conjugate multiple pyrroles to phosphopeptides. In addition, pyrrole has yet to be incorporated in peptides for EISA, though oligomeric pyrroles have been extensively explored for binding nucleic acids [68]. Based on a naphthylcapped phosphopeptide (Nap-ff $f_{p} y, \mathbf{1}$ ), we conjugated heteroaromatic dipyrrole or tripyrrole motifs at the $\mathrm{N}$-terminal of short peptides containing phosphotyrosine or phosphoserine and examined the bioactivity of the resulting phosphopeptides (2-10). Unexpectedly, enzymatic dephosphorylation of 2-10 rarely induces distinct morphological transitions of the peptide assemblies, such as the transition of nanoparticles to nanofibers, which is a transition observed in the case of $\mathbf{1}$ [43]. Incubating 2-10 with HeLa cells reveals that these phosphopeptides exhibit comparable inhibitory activity as that of $\mathbf{1}$ against the proliferation of HeLa cells at $200 \mu \mathrm{M}$. But $\mathbf{2 - 1 0}$ at $400 \mu \mathrm{M}$, differing drastically from $\mathbf{1}$, are largely compatible with HeLa cells, while 1, at $400 \mu \mathrm{M}$, significantly inhibits HeLa cells. These results suggest that morphological transition or extensive selfassembly triggered by enzymatic reactions likely is necessary for the inhibition of HeLa cells by EISA. This work, thus, provides useful insights for the development of phosphopeptide derivatives as enzyme substrates for controlling cell fate.

\section{Results and Discussion Molecular design}

As illustrated in Scheme 1, the phosphopeptide (Nap- $\left.\mathrm{ff}_{\mathrm{p}} \mathrm{y}, \mathbf{1}\right)$ that inhibits HeLa cells consists of three segments, naphthylacetyl (Nap) at the N-terminal of the peptide, a self-assembling motif (D-phenylalanine-D-phenylalanine (ff)) [69] as the main backbone, and an enzymatic trigger D-phosphotyrosine $(\mathrm{p} y)$. This design presents a substrate of alkaline phosphatase (ALP) for EISA. Based on this structure, a considerable number of studies have investigated the physical properties (enzyme-catalyzed hydrogelation or supramolecular structural transformation) $[62,70]$ and biological properties (cell viability, biostability, and cell-selective growth inhibition) $[43,62]$ of the naphthylacetyl N-terminal-capped phosphopeptides. These studies have produced a variety of phosphopeptides that selectively inhibit cancer cells $[38,64,65,71,72]$. Encouraged by the results from the naphthylacetyl capped phosphopeptides, we decided to use multiple $N$-methylpyrroles, as the heteroaromatic analog of naphthyl, to cap the N-terminal of phosphopeptides for EISA. According to this rationale, replacing the Nap capping group in $\mathbf{1}$ with a dipyrrole or a tripyrrole segment at the $\mathrm{N}$-terminal generates $\mathbf{2 a}$ and $\mathbf{2 b}$. Introducing two or three glycine residues between the pyrrole segment and the self-assembling segment produces $\mathbf{2} \mathbf{c}-\mathbf{h}$, which would help to understand the role of a spacer in the molecular structure. As the enantiomers of $\mathbf{2} \mathbf{g}$ and $\mathbf{2 h}$, respectively, $\mathbf{3 a}$ and $\mathbf{3 b}$ offer an opportunity to assess the effects of stereochemistry of the pyrrole-capped phosphopeptides. Substituting the D-phosphotyrosine $\left({ }_{p} y\right)$ in $\mathbf{2 g}$ and $\mathbf{2 h}$, by D-phosphoserine ( $\mathrm{p} s$ ), affords $\mathbf{4 a}$ and $\mathbf{4 b}$, respectively. Switching the D-phosphoserine in $\mathbf{4 a}$ and $\mathbf{4 b}$ by $\mathrm{L}$-phosphoserine $\left({ }_{\mathrm{p}} \mathrm{S}\right)$, creates $\mathbf{5 a}$ and $\mathbf{5 b}$. D-Trialanine replaces triglycine in $\mathbf{2 f - h}$ to produce $6 \mathbf{6}-\mathbf{c}$, which should resist to proteases, such as polyglycine hydrolases [73], which are known to cleave at the glycine-glycine site. The addition of an arginine residue in the backbone of $\mathbf{2 a}$ leads to 7, which bears an additional positive charge compared to $\mathbf{2 a}$. A D-tetraleucine $\left(1_{4}\right)$ replaces D-diphenylalanine (ff) in $\mathbf{2 d}$ and $\mathbf{2 e}$ to form $\mathbf{8 a}$ and $\mathbf{8 b}$, respectively. Adding a Boc protecting group at the $\mathrm{N}$-terminus of $\mathbf{2 a}$ produces 9 . Attaching a guanidinoacetic acid motif to $\mathbf{2 f}$ and $\mathbf{2 g}$ results in 10a and 10b. 9 and 10 would help test the effects of additional $\mathrm{N}$-terminal modifications. To examine the necessity of enzymatic dephosphorylation, we replaced D-phosphotyrosine ( $\mathrm{p}_{\mathrm{p}}$ ) in $\mathbf{2 g}, \mathbf{2 h}, \mathbf{6 a}-\mathbf{c}$ by D-tyrosine to yield 11a, 11b, 12a-c, respectively. Attaching $N$-methylpyrrole on the sidechain of NBD-ffky or NBD-ffk $\mathrm{p}$ [66], another previously studied selfassembling peptide, produces 13 and 14. In addition, 15a-c consist of only pyrrole and glycine units, which should help delineate the roles of the self-assembling motif and the enzymatic triggers.

\section{Synthesis}

The synthesis of the designed peptides combines solution synthesis of the enzyme trigger or the fluorophore with the solidphase synthesis of the pyrrole-peptide conjugates. We used phosphorus pentoxide and phosphoric acid to react with D-tyrosine, L-tyrosine, L-serine, or D-serine to produce D-phosphotyrosine, L-phosphotyrosine, L-phosphoserine, or D-phosphoserine, respectively. After being protected by an Fmoc group, these phosphorylated amino acids are suitable for solid-phase synthesis. We also used solution-phase synthesis to synthesize NBD- 


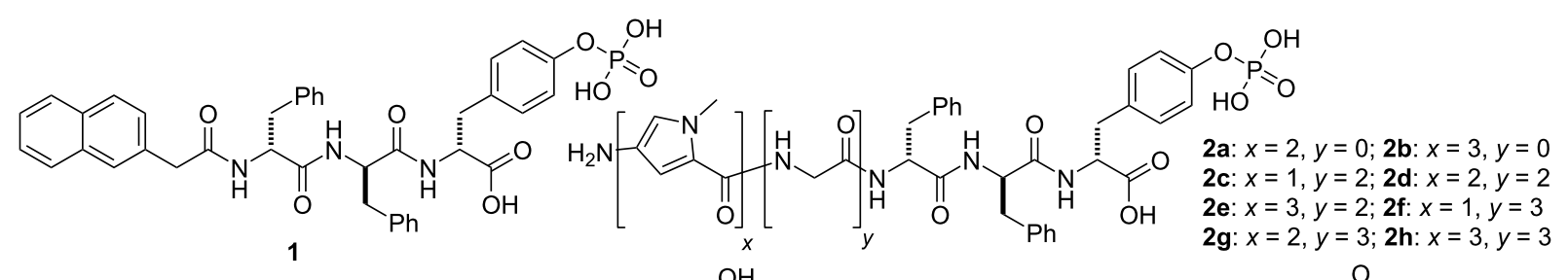
(n) (n) (n) ${ }_{\mathrm{H}_{2} \mathrm{~N}} \stackrel{\mathrm{NH}}{\mathrm{NH}}$

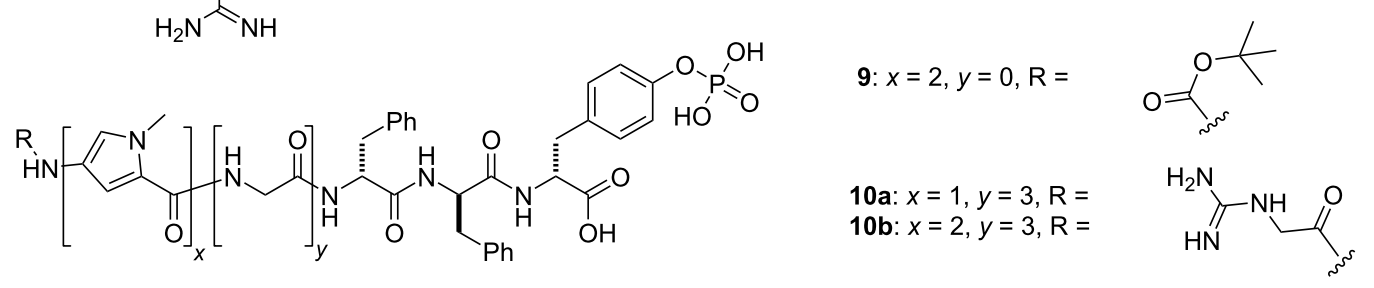
(12: $x=3$ (n) $15 \mathrm{a}: x=2, y=2$
$\mathrm{O}]_{x}$
$\begin{array}{r}15 \mathrm{~b}: x=2, y=3 \\ 15 \mathrm{c}: x=3, y=3\end{array}$ 
$\beta$-alanine according to the reported procedures [66]. We used standard Fmoc solid-phase peptide synthesis (SPPS) to generate the peptide segments $\left((\mathrm{G} / \mathrm{GG} / \mathrm{GGG}) \mathrm{ff}_{\mathrm{p}} \mathrm{y}\right.$ for $\mathbf{2 a}-\mathbf{h}, \mathbf{9}, \mathbf{1 0 a}, \mathbf{b}$, $\mathrm{GGGFF}_{\mathrm{p}} \mathrm{Y}$ for $\mathbf{3 a}, \mathbf{b}, \mathrm{GGGff}_{\mathrm{p}} \mathrm{s}$ for $\mathbf{4 a}, \mathbf{b}, \mathrm{GGGff}_{\mathrm{p}} \mathrm{S}$ for $\mathbf{5 a}, \mathbf{b}$, aaaff $\mathrm{p}$ y for $\mathbf{6 a}-\mathbf{c}, \operatorname{rff}_{\mathrm{p}} \mathrm{y}$ for $\mathbf{7}, \mathrm{GGllll}_{\mathrm{p}} \mathrm{y}$ for $\mathbf{8 a}, \mathbf{b}$, GGGffy for 11a,b, aaaffy for 12a-c, NBD-ffky for 13, NBD-ffk $\mathrm{p}$ for 14, $\mathrm{GG}(\mathrm{G})$ for $15 \mathrm{a}-\mathbf{c})$. Then, we introduced the $N$-methylpyrrole (Py) units into the peptides obtained via solution-phase amide bond formation to produce $\mathbf{2 a}-\mathbf{h}, \mathbf{3 a}, \mathbf{b}, \mathbf{4 a}, \mathbf{b}, \mathbf{5 a}, \mathbf{b}, \mathbf{6 a}-\mathbf{c}, \mathbf{7}$, 8a,b, 11a,b, 12a-c, 13, 14, and 15a-c. We conjugated two Py units successively to the peptide $\mathrm{ff}_{\mathrm{p}} \mathrm{y}$ and kept the Boc protecting group of the second Py unit to give a Boc-capped product, 9. We added guanidinoacetic acid to Py-GGGff $\mathrm{p}$ y and $(\mathrm{Py})_{2}-\mathrm{GGGff}_{\mathrm{p}} \mathrm{y}$ for making 10a and $\mathbf{1 0 b}$, respectively. All the products were purified by HPLC.

\section{Bioactivity}

We examined the cytotoxicity of the synthesized compounds by incubating them with HeLa cells because HeLa cells overexpress ALP and are widely available. By incubating $200 \mu \mathrm{M}$ of each compound with HeLa cells for 24 hours, we employed MTT assay to determine the cell viability of the HeLa cells. As shown in Figure 1, the MTT results indicate that most of the pyrrole-conjugated phosphopeptides, at $200 \mu \mathrm{M}$, are comparable with the activity of $\mathbf{1}$ against the HeLa cells. In terms of the pyrrole-conjugated $\mathrm{ff}_{\mathrm{p}} \mathrm{y}$ series $(\mathbf{2} \mathbf{a}-\mathbf{h})$, all of the compounds are rather compatible with the cells, with the cell viability ranging from $92.8 \%$ (2f) to $142.6 \%$ (2b). The incubation of the L-enantiomers 3a and $\mathbf{3 b}$ with HeLa cells results in cell viabilities of $86.0 \%$ and $97.2 \%$, respectively. While L-phosphoserine peptides, 5a and 5b, hardly inhibit the HeLa cells, D-phosphoserine peptides, $\mathbf{4 a}$ and $\mathbf{4 b}$, moderately inhibit the proliferation of the HeLa cells, among which $\mathbf{4 a}$ decreases cell viability to $69.2 \%$. 6a-c, containing a D-trialanine motif and one to three pyrrole motifs at the N-terminal, hardly inhibit the HeLa cells. Compound 7 , formed by the introduction of a $\mathrm{D}$-arginine residue into $\mathbf{2 a}$, exhibits similar cytotoxicity as that of $\mathbf{2 a}$. $\mathbf{8 a}$ and $\mathbf{8 b}$, formed by replacing the ff motif in $\mathbf{2 d}$ and $\mathbf{2 e}$ with $1_{4}$, exhibit slight and little cytotoxicity, respectively. Capping the $\mathrm{N}$-terminus with a Boc-protecting group (9) or a guanidinoacetic acid motif (10a and 10b) renders the molecules with higher cytotoxicity (resulting in cell viabilities of about $70 \%$ ) than those of $\mathbf{2 f}$ and $\mathbf{2 g}$. Compounds without phosphorylation (11a, 11b and 12a-c) show similar activity compared to their

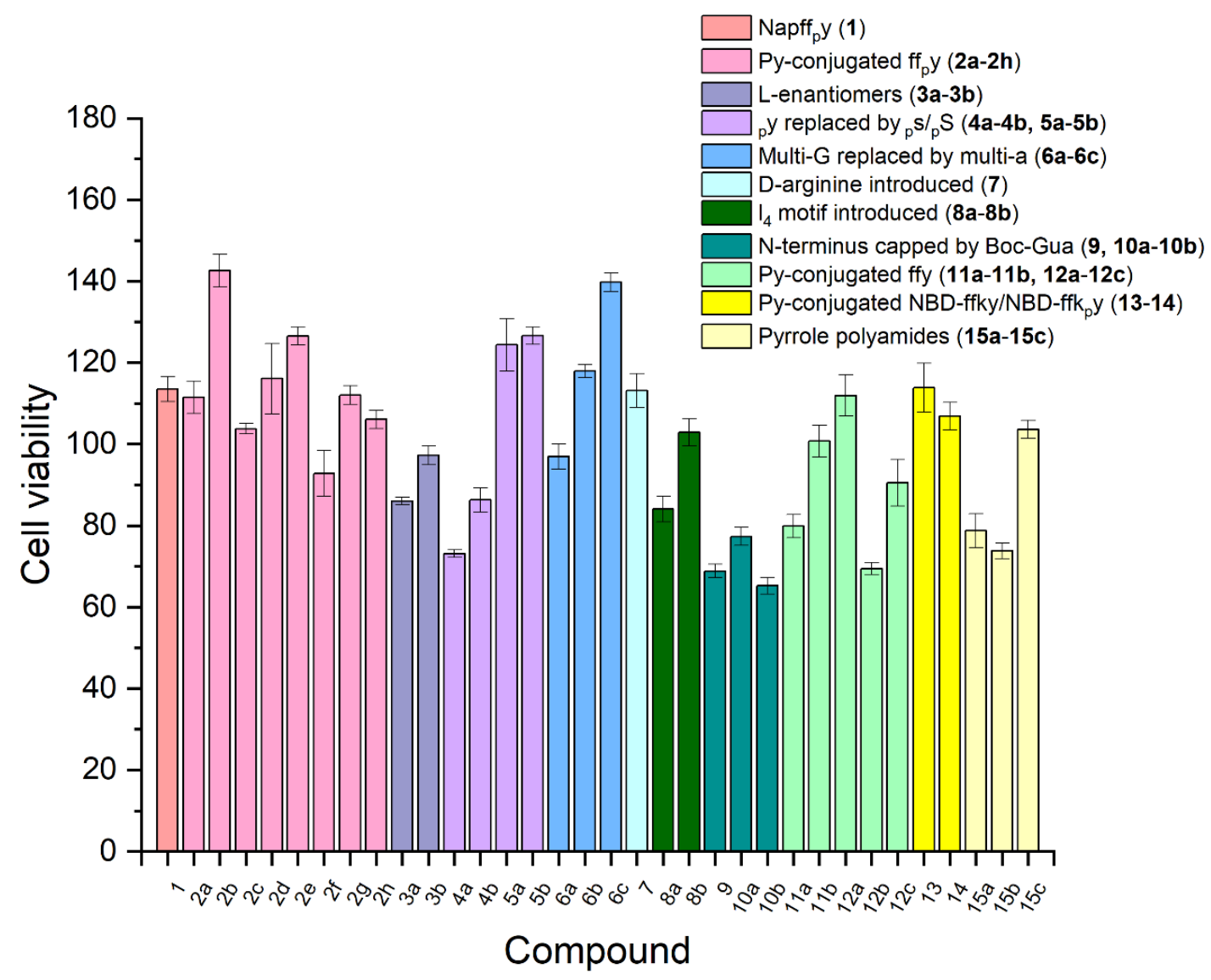

Figure 1: Cell viability of HeLa cells treated with $200 \mu \mathrm{M}$ of each compound for $24 \mathrm{~h}$. 
phosphorylated counterparts. These results indicate that these peptide assemblies are rather compatible with cells. Compounds 13 and 14, both possessing a pyrrole building block on the side chain, hardly inhibit the HeLa cells. While 15a and $\mathbf{1 5 b}$ exhibit slight cytotoxicity, $\mathbf{1 5 c}$ is less cytotoxic. This result agrees with the observation that dipyrrole-conjugated peptides, in general, exhibit higher inhibitory activity against HeLa cells than mono- or tripyrrole-conjugated peptides do. It is interesting that $\mathbf{4 a}$ exhibits higher inhibitory activity than that of $\mathbf{2 g}$, despite that 4a bears D-phosphoserine and $\mathbf{2 g}$ bears D-phosphotyrosine. This result likely warrants further investigation on $\mathbf{4 a}$. Another dipyrrole-conjugated peptide, $\mathbf{6 b}$, was also selected for further study as a comparison to $\mathbf{4 a}$ since it shows good cell compatibility at $200 \mu \mathrm{M}$.

We also compared the cell viability of HeLa cells incubated with $\mathbf{1}, \mathbf{4 a}$, and $\mathbf{6 b}$ at different concentrations for 3 days. As shown in Figure 2, the three compounds result in different cell viabilities versus concentration and incubation time. 1 hardly inhibits the proliferation of the cells at concentrations lower than $100 \mu \mathrm{M}$ over the 3 days, while $200 \mu \mathrm{M}$ of 1 begins to reduce cell viability on day 3 . At the concentration of $400 \mu \mathrm{M}$, 1 drastically decreases the cell viability to $52.0 \%$ on day 1 , while longer incubation time further inhibits cell proliferation, resulting in a cell viability of only $3.4 \%$ on day 3 . This result agrees well with previous results $[43,62]$. Unlike 1, 4a slightly inhibits cell proliferation, with cell viability ranging from $89.6 \%$ to $72.3 \%$ with increasing concentrations from 20 to $400 \mu \mathrm{M}$. However, the inhibitory effect of 4a largely vanishes on day 2 and 3 of the incubation. This result implies that cells likely are able to degrade $4 \mathbf{a}$ overtime. Unlike 1 and $\mathbf{4 a}, \mathbf{6 b}$, exhibiting little cytotoxicity with increasing compound concentration or incubation time, is rather compatible to the cells. These results indicate that the replacement of Nap by pyrroles largely results in cell compatible phosphopeptide derivatives.

\section{Enzymatic conversion}

To further investigate the reason for the different activities in cell assays among the three compounds, 1, 4a and $\mathbf{6 b}$, we employed transmission electron microscopy (TEM) to study the morphologies of the assemblies of these compounds before and after enzymatic dephosphorylation. Previous literature has demonstrated that $\mathbf{1}$, as a precursor, is capable of forming hydrogels upon dephosphorylation catalyzed by ALP [43,62]. To be more specific, ALP enables a morphological transition from nanoparticles of $\mathbf{1}$ to networks of nanofibers of the corre-
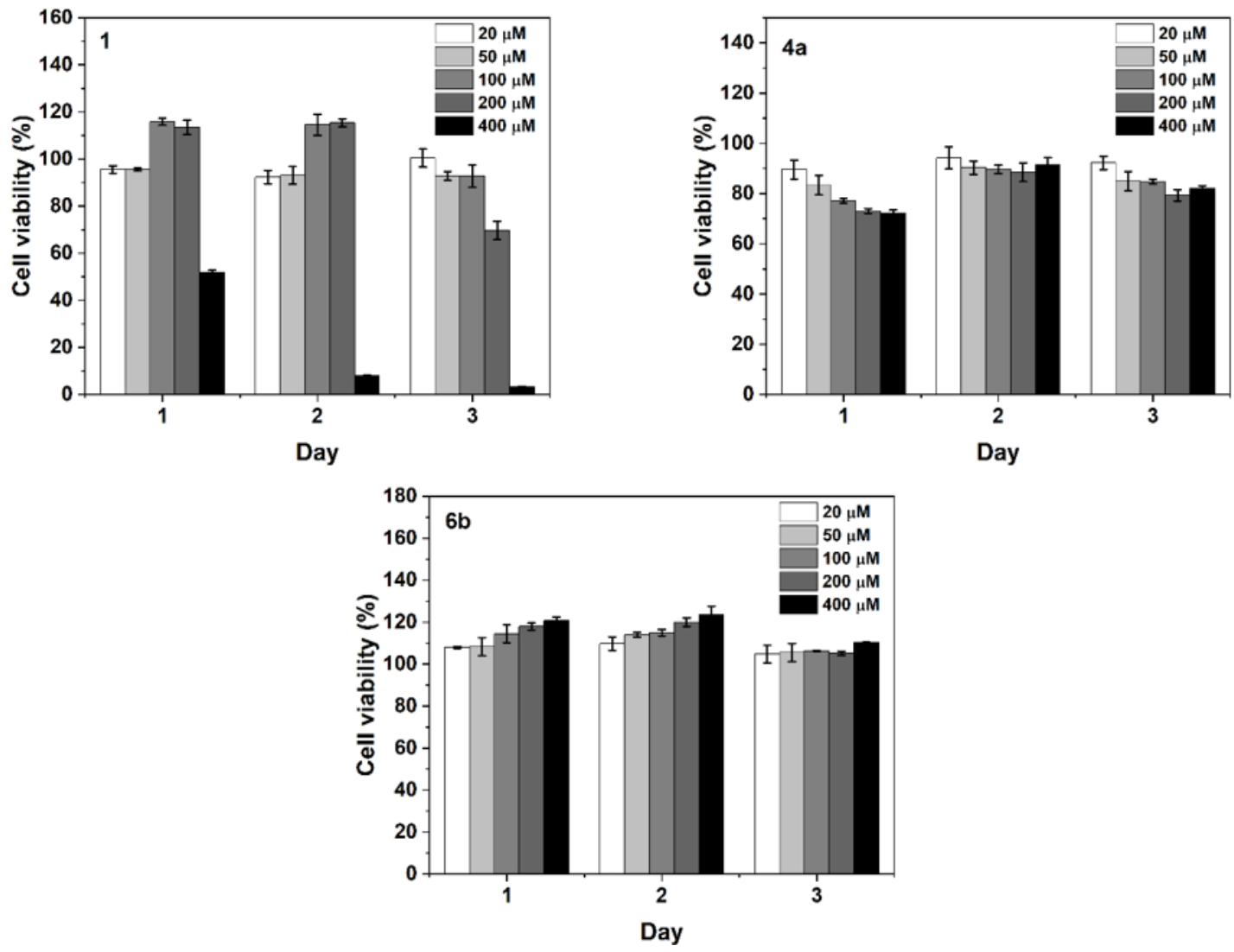

Figure 2: Cell viability of HeLa cells treated with $20 \mu \mathrm{M}, 50 \mu \mathrm{M}, 100 \mu \mathrm{M}, 200 \mu \mathrm{M}$ and $400 \mu \mathrm{M}$ of 1, 4a and $6 \mathrm{~b}$ for 1,2 , and 3 days. 
sponding dephosphorylated peptides, resulting in hydrogelation (Figure 3A) [62]. In comparison with 1, 4a, forming networks of nanoparticles at $400 \mu \mathrm{M}$ and $200 \mu \mathrm{M}$, exhibits little change in the morphology of the assemblies after being incubated with $1 \mathrm{U} / \mathrm{mL}$ of ALP for $24 \mathrm{~h}$ (Figure 3B), although LC-MS confirms the enzymatic dephosphorylation of $4 \mathbf{a}$ (Supporting

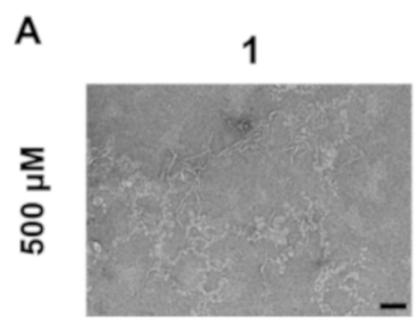

B
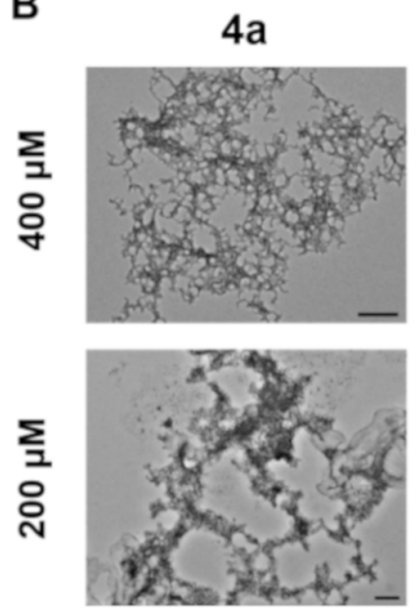

$6 b$
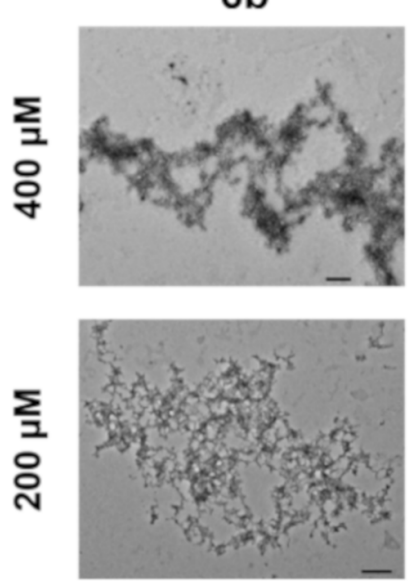

$1+\mathrm{ALP}$

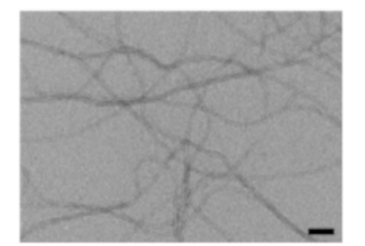

$4 a+A L P$
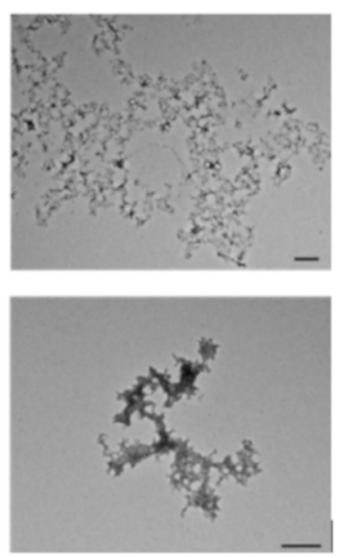

$6 b+A L P$
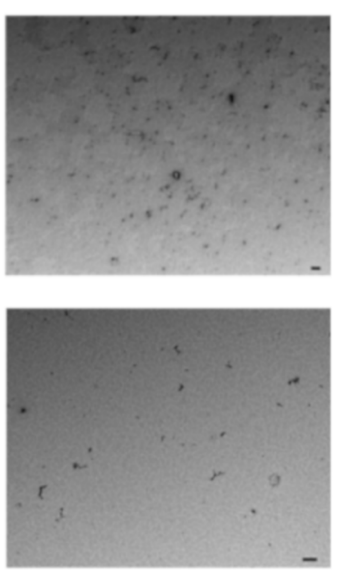

Figure 3: A) TEM images of 1 before and after addition of ALP $(0.5 \mathrm{U} / \mathrm{mL})$ in PBS buffer ( $\mathrm{pH} 7.4)$. Scale bar is $100 \mathrm{~nm}$. Figure $3 A$ was reprinted with permission from [62] https://pubs.acs.org/doi/10.1021/ bm5010355, Copyright 2014 American Chemical Society. This content is not subjected to CC-BY 4.0. Permission requests related to the material excerpted should be directed to the ACS. B) TEM images of representative pyrrole-conjugated peptides $\mathbf{4 a}$ and $\mathbf{6} \mathbf{b}$ before and after the addition of ALP (1 U/mL) in PBS buffer ( $\mathrm{pH} 7.4)$. Scale bar is $200 \mathrm{~nm}$.
Information File 1, Figure S32). Similarly, $\mathbf{6 b}$ also forms dense nanoparticulate networks at $400 \mu \mathrm{M}$ and $200 \mu \mathrm{M}$ (Figure 3B). After the addition of $1 \mathrm{U} / \mathrm{mL}$ of ALP for $24 \mathrm{~h}$, the nanoparticles remain, although the networks dissociate. Similarly, LC-MS confirms the enzymatic dephosphorylation of $\mathbf{6 b}$ (Supporting Information File 1, Figure S33) after the addition of ALP. In addition to the TEM images, we used circular dichroism (CD) to reveal the secondary structures of the assemblies before and after enzymatic action. The spectra show a significant change in the signal upon ALP treatment for 1, but merely slight changes for $\mathbf{4 a}$ and $\mathbf{6 b}$, which are consistent with the TEM images (Supporting Information File 1, Figure S34). The differences in the morphological transition between $\mathbf{1}$ and $\mathbf{4 a}$ or $\mathbf{6 b}$ revealed by TEM and CD suggest that the shape-shifting (from nanoparticles to nanofibers) likely contributes to the cell death caused by 1 over days 2 and 3. These results together indicate the drastic morphological changes of phosphopeptides upon the addition of ALP may serve as a useful indicator to predict the cell compatibility or cytotoxicity of phosphopeptides.

\section{Conclusion}

In summary, this work reports the design and synthesis of a series of pyrrole-conjugated phosphopeptides. These pyrroleconjugated phosphopeptides are largely cell compatible and are unable to undergo drastic morphological transitions, such as from nanoparticles to nanofibers. These results, contrary to the result obtained from 1, suggest that the morphological transition of the peptide assemblies resulted from enzymatic reaction likely is responsible for disrupting cellular processes to inhibit cells. Other factors, such as endocytosis of the phosphopeptides [74] and the cellular localization of the peptide assemblies [75], certainly could contribute to the cell compatibilities of the pyrrole-conjugated phosphopeptides, which remain to be determined.

\section{Supporting Information}

\section{Supporting Information File 1 \\ Experiment part. \\ [https://www.beilstein-journals.org/bjoc/content/ \\ supplementary/1860-5397-18-17-S1.pdf]}

\section{Funding}

This work is partially supported by NIH (R01CA142746).

\section{ORCID ${ }^{\circledR}$ iDs}

Qiuxin Zhang - https://orcid.org/0000-0002-8659-3569

Bing Xu - https://orcid.org/0000-0002-4639-387X 


\section{References}

1. Acar, H.; Srivastava, S.; Chung, E. J.; Schnorenberg, M. R.; Barrett, J. C.; LaBelle, J. L.; Tirrell, M. Adv. Drug Delivery Rev. 2017, 110-111, 65-79. doi:10.1016/j.addr.2016.08.006

2. Kim, B. J.; Yang, D.; Xu, B. Trends Chem. 2020, 2, 71-83. doi:10.1016/j.trechm.2019.09.004

3. Cheetham, A. G.; Chakroun, R. W.; Ma, W.; Cui, H. Chem. Soc. Rev. 2017, 46, 6638-6663. doi:10.1039/c7cs00521k

4. Ulijn, R. V.; Jerala, R. Chem. Soc. Rev. 2018, 47, 3391-3394. doi:10.1039/c8cs90055h

5. Gazit, E. Chem. Soc. Rev. 2007, 36, 1263-1269. doi:10.1039/b605536m

6. Bietsch, J.; Olson, M.; Wang, G. Gels 2021, 7, 134. doi:10.3390/gels7030134

7. Brito, A.; Abul-Haija, Y. M.; da Costa, D. S.; Novoa-Carballal, R.; Reis, R. L.; Ulijn, R. V.; Pires, R. A.; Pashkuleva, I. Chem. Sci. 2019, 10, 2385-2390. doi:10.1039/c8sc04361b

8. Gao, Y.; Kuang, Y.; Guo, Z.-F.; Guo, Z.; Krauss, I. J.; Xu, B. J. Am. Chem. Soc. 2009, 131, 13576-13577. doi:10.1021/ja904411z

9. Li, J.; Gao, Y.; Kuang, Y.; Shi, J.; Du, X.; Zhou, J.; Wang, H.; Yang, Z.; Xu, B. J. Am. Chem. Soc. 2013, 135, 9907-9914. doi:10.1021/ja404215g

10. Cheetham, A. G.; Zhang, P.; Lin, Y.-a.; Lock, L. L.; Cui, H. J. Am. Chem. Soc. 2013, 135, 2907-2910. doi:10.1021/ja3115983

11. Liang, C.; Yan, X.; Zhang, R.; Xu, T.; Zheng, D.; Tan, Z.; Chen, Y.; Gao, Z.; Wang, L.; Li, X.; Yang, Z. J. Controlled Release 2020, 317, 109-117. doi:10.1016/j.jconrel.2019.11.028

12. Rele, S.; Song, Y.; Apkarian, R. P.; Qu, Z.; Conticello, V. P.; Chaikof, E. L. J. Am. Chem. Soc. 2007, 129, 14780-14787. doi:10.1021/ja0758990

13. Salick, D. A.; Kretsinger, J. K.; Pochan, D. J.; Schneider, J. P. J. Am. Chem. Soc. 2007, 129, 14793-14799. doi:10.1021/ja076300z

14. Chen, W.; Yang, S.; Li, S.; Lang, J. C.; Mao, C.; Kroll, P.; Tang, L.; Dong, H. ACS Appl. Mater. Interfaces 2019, 11, 28681-28689. doi:10.1021/acsami.9b09583

15. Hartgerink, J. D.; Beniash, E.; Stupp, S. I. Science 2001, 294, 1684-1688. doi:10.1126/science.1063187

16. Lee, S.-Y.; Gao, X.; Matsui, H. J. Am. Chem. Soc. 2007, 129, 2954-2958. doi:10.1021/ja0677057

17. Burkoth, T. S.; Benzinger, T. L. S.; Urban, V.; Morgan, D. M.; Gregory, D. M.; Thiyagarajan, P.; Botto, R. E.; Meredith, S. C.; Lynn, D. G. J. Am. Chem. Soc. 2000, 122, 7883-7889. doi:10.1021/ja000645z

18. Silva, G. A.; Czeisler, C.; Niece, K. L.; Beniash, E.; Harrington, D. A.; Kessler, J. A.; Stupp, S. I. Science 2004, 303, 1352-1355. doi:10.1126/science.1093783

19. Tang, J. D.; Mura, C.; Lampe, K. J. J. Am. Chem. Soc. 2019, 141, 4886-4899. doi:10.1021/jacs.8b13363

20. Yang, Z.; Gu, H.; Fu, D.; Gao, P.; Lam, J. K.; Xu, B. Adv. Mater. (Weinheim, Ger.) 2004, 16, 1440-1444. doi:10.1002/adma.200400340

21. Toledano, S.; Williams, R. J.; Jayawarna, V.; Ulijn, R. V. J. Am. Chem. Soc. 2006, 128, 1070-1071. doi:10.1021/ja056549|

22. Yang, Z.; Liang, G.; Guo, Z.; Guo, Z.; Xu, B. Angew. Chem., Int. Ed. 2007, 46, 8216-8219. doi:10.1002/anie.200701697

23. Dragulescu-Andrasi, A.; Kothapalli, S.-R.; Tikhomirov, G. A.; Rao, J.; Gambhir, S. S. J. Am. Chem. Soc. 2013, 135, 11015-11022. doi:10.1021/ja4010078
24. Wang, H.; Chen, P.; Wu, H.; Zou, P.; Wu, J.; Liu, Y.; Liang, G. Anal. Chem. (Washington, DC, U. S.) 2019, 91, 14842-14845. doi:10.1021/acs.analchem.9b04788

25. Chen, Z.; Chen, M.; Zhou, K.; Rao, J. Angew. Chem., Int. Ed. 2020, 59, 7864-7870. doi:10.1002/anie.201916352

26. Nejadnik, H.; Ye, D.; Lenkov, O. D.; Donig, J. S.; Martin, J. E.; Castillo, R.; Derugin, N.; Sennino, B.; Rao, J.; Daldrup-Link, H. ACS Nano 2015, 9, 1150-1160. doi:10.1021/nn504494c

27. Ye, D.; Shuhendler, A. J.; Cui, L.; Tong, L.; Tee, S. S.; Tikhomirov, G.; Felsher, D. W.; Rao, J. Nat. Chem. 2014, 6, 519-526. doi:10.1038/nchem.1920

28. Hu, Y.; Zhang, J.; Miao, Y.; Wen, X.; Wang, J.; Sun, Y.; Chen, Y.; Lin, J.; Qiu, L.; Guo, K.; Chen, H.-Y.; Ye, D. Angew. Chem., Int. Ed. 2021, 60, 18082-18093. doi:10.1002/anie.202103307

29. Yan, R.; Hu, Y.; Liu, F.; Wei, S.; Fang, D.; Shuhendler, A. J.; Liu, H.; Chen, H.-Y.; Ye, D. J. Am. Chem. Soc. 2019, 141, 10331-10341. doi:10.1021/jacs.9b03649

30. Zhang, M.; Wang, C.; Yang, C.; Wu, H.; Xu, H.; Liang, G. Anal. Chem. (Washington, DC, U. S.) 2021, 93, 5665-5669. doi:10.1021/acs.analchem.1c00220

31. Chen, P.; Wang, H.; Wu, H.; Zou, P.; Wang, C.; Liu, X.; Pan, Y.; Liu, Y.; Liang, G. Anal. Chem. (Washington, DC, U. S.) 2021, 93, 6329-6334. doi:10.1021/acs.analchem.1c00747

32. Lin, Y.-X.; Qiao, S.-L.; Wang, Y.; Zhang, R.-X.; An, H.-W.; Ma, Y.; Rajapaksha, R. P. Y. J.; Qiao, Z.-Y.; Wang, L.; Wang, H. ACS Nano 2017, 11, 1826-1839. doi:10.1021/acsnano.6b07843

33. Wang, C.; Du, W.; Zhang, T.; Liang, G. Anal. Chem. (Washington, DC, U. S.) 2020, 92, 15275-15279. doi:10.1021/acs.analchem.0c04227

34. Li, I.-C.; Hartgerink, J. D. J. Am. Chem. Soc. 2017, 139, 8044-8050. doi:10.1021/jacs.7b04655

35. Zhou, J.; Du, X.; Gao, Y.; Shi, J.; Xu, B. J. Am. Chem. Soc. 2014, 136, 2970-2973. doi:10.1021/ja4127399

36. Feng, Z.; Wang, H.; Wang, S.; Zhang, Q.; Zhang, X.; Rodal, A. A.; Xu, B. J. Am. Chem. Soc. 2018, 140, 9566-9573. doi:10.1021/jacs.8b04641

37. Wang, H.; Feng, Z.; Tan, W.; Xu, B. Bioconjugate Chem. 2019, 30, 2528-2532. doi:10.1021/acs.bioconjchem.9b00524

38. Wang, H.; Feng, Z.; Wang, Y.; Zhou, R.; Yang, Z.; Xu, B. J. Am. Chem. Soc. 2016, 138, 16046-16055. doi:10.1021/jacs.6b09783

39. He, H.; Wang, J.; Wang, H.; Zhou, N.; Yang, D.; Green, D. R.; Xu, B. J. Am. Chem. Soc. 2018, 140, 1215-1218. doi:10.1021/jacs.7b11582

40. Zhou, L.; Lu, D.; Wang, Q.; Liu, S.; Lin, Q.; Sun, H. Biosens. Bioelectron. 2017, 91, 699-705. doi:10.1016/j.bios.2016.12.055

41. Liu, S.; Zhang, Q.; Shy, A. N.; Yi, M.; He, H.; Lu, S.; Xu, B. J. Am. Chem. Soc. 2021, 143, 15852-15862. doi:10.1021/jacs.1c07923

42. Kuang, Y.; Miki, K.; Parr, C. J. C.; Hayashi, K.; Takei, I.; Li, J.; Iwasaki, M.; Nakagawa, M.; Yoshida, Y.; Saito, H. Cell Chem. Biol. 2017, 24, 685-694.e4. doi:10.1016/j.chembiol.2017.04.010

43. Kuang, Y.; Shi, J.; Li, J.; Yuan, D.; Alberti, K. A.; Xu, Q.; Xu, B. Angew. Chem., Int. Ed. 2014, 53, 8104-8107. doi:10.1002/anie.201402216

44. Feng, Z.; Han, X.; Wang, H.; Tang, T.; Xu, B. Chem 2019, 5, 2442-2449. doi:10.1016/j.chempr.2019.06.020

45. Zhou, J.; Du, X.; Yamagata, N.; Xu, B. J. Am. Chem. Soc. 2016, 138, 3813-3823. doi:10.1021/jacs.5b13541 
46. Tanaka, A.; Fukuoka, Y.; Morimoto, Y.; Honjo, T.; Koda, D.; Goto, M.; Maruyama, T. J. Am. Chem. Soc. 2015, 137, 770-775. doi:10.1021/ja510156v

47. Li, J.; Shi, K.; Sabet, Z. F.; Fu, W.; Zhou, H.; Xu, S.; Liu, T.; You, M.; Cao, M.; Xu, M.; Cui, X.; Hu, B.; Liu, Y.; Chen, C. Sci. Adv. 2019, 5, eaax0937. doi:10.1126/sciadv.aax0937

48. Yang, Z. M.; Xu, K. M.; Guo, Z. F.; Guo, Z. H.; Xu, B. Adv. Mater. (Weinheim, Ger.) 2007, 19, 3152-3156. doi:10.1002/adma.200701971

49. Gao, J.; Zhan, J.; Yang, Z. Adv. Mater. (Weinheim, Ger.) 2020, 32 , 1805798. doi:10.1002/adma.201805798

50. Yao, Q.; Huang, Z.; Liu, D.; Chen, J.; Gao, Y. Adv. Mater. (Weinheim, Ger.) 2019, 31, 1804814. doi:10.1002/adma.201804814

51. Li, L.-L.; Liu, W.-J.; Cai, Q.; Wang, H. J. Controlled Release 2017, 259, e82-e83. doi:10.1016/j.jconrel.2017.03.182

52. Hu, X.; Yang, P.; He, J.; Liang, R.; Niu, D.; Wang, H.; Li, Y. J. Mater. Chem. B 2017, 5, 5931-5936. doi:10.1039/c7tb01268c

53. Hu, L.; Li, Y.; Lin, X.; Huo, Y.; Zhang, H.; Wang, H. Angew. Chem., Int. Ed. 2021, 60, 21807-21816. doi:10.1002/anie.202103507

54. Pires, R. A.; Abul-Haija, Y. M.; Costa, D. S.; Novoa-Carballal, R.; Reis, R. L.; Ulijn, R. V.; Pashkuleva, I. J. Am. Chem. Soc. 2015, 137, 576-579. doi:10.1021/ja5111893

55. Wang, H.; Shi, J.; Feng, Z.; Zhou, R.; Wang, S.; Rodal, A. A.; Xu, B. Angew. Chem., Int. Ed. 2017, 56, 16297-16301. doi:10.1002/anie.201710269

56. Yang, Z.; Liang, G.; Xu, B. Acc. Chem. Res. 2008, 41, 315-326. doi:10.1021/ar7001914

57. Zhou, J.; Xu, B. Bioconjugate Chem. 2015, 26, 987-999. doi:10.1021/acs.bioconjchem.5b00196

58. Yang, Z.; Ma, M.; Xu, B. Soft Matter 2009, 5, 2546-2548. doi:10.1039/b908206a

59. Wang, H.; Feng, Z.; Del Signore, S. J.; Rodal, A. A.; Xu, B. J. Am. Chem. Soc. 2018, 140, 3505-3509. doi:10.1021/jacs.7b13307

60. Feng, Z.; Wang, H.; Wang, F.; Oh, Y.; Berciu, C.; Cui, Q.; Egelman, E. H.; Xu, B. Cell Rep. Phys. Sci. 2020, 1, 100085. doi:10.1016/j.xcrp.2020.100085

61. Wang, H.; Feng, Z.; Xu, B. Angew. Chem., Int. Ed. 2019, 58, 5567-5571. doi:10.1002/anie.201812998

62. Shi, J.; Du, X.; Yuan, D.; Zhou, J.; Zhou, N.; Huang, Y.; Xu, B. Biomacromolecules 2014, 15, 3559-3568. doi:10.1021/bm5010355

63. Yang, D.; He, H.; Kim, B. J.; Xu, B. Bioconjugate Chem. 2021, 32, 502-506. doi:10.1021/acs.bioconjchem.1c00032

64. Tan, W.; Zhang, Q.; Wang, J.; Yi, M.; He, H.; Xu, B. Angew. Chem., Int. Ed. 2021, 60, 12796-12801. doi:10.1002/anie.202102601

65. He, H.; Liu, S.; Wu, D.; Xu, B. Angew. Chem., Int. Ed. 2020, 59, 16445-16450. doi:10.1002/anie.202006290

66. Wang, H.; Feng, Z.; Xu, B. J. Am. Chem. Soc. 2019, 141, 7271-7274. doi:10.1021/jacs.9b03346

67. Li, X.; Kuang, Y.; Lin, H.-C.; Gao, Y.; Shi, J.; Xu, B. Angew. Chem., Int. Ed. 2011, 50, 9365-9369. doi:10.1002/anie.201103641

68. Dervan, P. B. Bioorg. Med. Chem. 2001, 9, 2215-2235. doi:10.1016/s0968-0896(01)00262-0

69. Reches, M.; Gazit, E. Science 2003, 300, 625-627. doi:10.1126/science.1082387

70. Yang, Z.; Liang, G.; Ma, M.; Gao, Y.; Xu, B. Small 2007, 3, 558-562. doi:10.1002/smll.200700015
71. Wang, J.; Tan, W.; Li, G.; Wu, D.; He, H.; Xu, J.; Yi, M.; Zhang, Y.; Aghvami, S. A.; Fraden, S.; Xu, B. Chem. - Eur. J. 2020, 26 , 15116-15120. doi:10.1002/chem.202002974

72. Huang, A.; Ou, C.; Cai, Y.; Wang, Z.; Li, H.; Yang, Z.; Chen, M. RSC Adv. 2016, 6, 32519-32522. doi:10.1039/c6ra01676f

73. Naumann, T. A.; Naldrett, M. J.; Ward, T. J.; Price, N. P. J. Protein Sci. 2015, 24, 1147-1157. doi:10.1002/pro.2705

74. He, H.; Guo, J.; Xu, J.; Wang, J.; Liu, S.; Xu, B. Nano Lett. 2021, 21, 4078-4085. doi:10.1021/acs.nanolett.1c01029

75. Yang, D.; Kim, B. J.; He, H.; Xu, B. Pept. Sci. 2021, 113, e24173. doi:10.1002/pep2.24173

\section{License and Terms}

This is an open access article licensed under the terms of the Beilstein-Institut Open Access License Agreement (https://www.beilstein-journals.org/bjoc/terms), which is identical to the Creative Commons Attribution 4.0 International License

(https://creativecommons.org/licenses/by/4.0). The reuse of material under this license requires that the author(s), source and license are credited. Third-party material in this article could be subject to other licenses (typically indicated in the credit line), and in this case, users are required to obtain permission from the license holder to reuse the material.

The definitive version of this article is the electronic one which can be found at: https://doi.org/10.3762/bjoc. 18.17 